\title{
IMPROVEMENT OF FROST RESISTANCE OF GRAPEVINE
}

\author{
Marian Lixandru $^{1}{ }^{*}$, Sergiu Fendrihan ${ }^{1,2}$ \\ ${ }^{1}$ Research and Development Institute for Plant Protection Bucharest, Romania \\ ${ }^{2}$ Western University «Vasile Goldiș» Arad \\ *Correspondence address: \\ Research-Development Institute for Plant Protection \\ 8 Ion Ionescu de la Brad 013813, Bucharest, Romania \\ Phone: + 40212693231 \\ Fax: + 40212693239 \\ Email: lixandrumarian@yahoo.com \\ http://www.doi.org/10.54574/RJPP.13.04
}

\begin{abstract}
The experiments took place in the village Hotarele (Giurgiu County) comprising a vineyard area of $1.5 \mathrm{ha}$, with the Muscat Ottonel variety. From batches treated with copper sulphate with a concentration of $1.5 \%$ before the fall of the leaves and 3\% after the fall of the leaves, samples were taken and their evolution was constantly monitored before and after the cold season. The buds and wood viability at negative temperatures of $-15,-18,-21^{\circ} \mathrm{C}$ and the content in reserve substances were analyzed. It was found that the vines treated with copper sulfate have a higher viability, therefore a better resistance to frost as well as biochemical characteristics higher content of reserve substances, which support this resistance.
\end{abstract}

Key words: frost resistance, copper sulfate, vines viability, reserve substance content

\section{INTRODUCTION}

The resistance to frost is essential for the vineyards in the temperate continental areas with very low temperatures in winter time which affects the viability of buds and wood of grapevines. Freezing injury results in lower production of vineyards (Fennell, 2004). A model of cold hardiness of buds was issued by American scientists (Ferguson et al., 2011) which allowed to predict the possible injuries from frost, and to see differences between cultivars in hardiness. Older studies present the inner biological and biochemical traits like growth regulators dehydrogenase enzymes content of pigment and $\mathrm{P}$ an $\mathrm{N}$ compounds and other to explain the resistance to frost of grape vines and the main strategies applied from site o plantation and irrigations and nutrient in soil, spraying with chemicals and frost monitoring system (Evans, 2000).

The genetic investigation of low temperature treated Vitis amurensis showed a down regulation of about 69 genes and some of them abundantly regulated after cold acclimatization (Wu et al., 2014). Another fact is that the plant-pathogen interaction pathways were linked to the cold acclimation. Differences of transcriptional profiles were seen between low temperature and freeze shock (Londo et al., 2018). The accumulation of potential protective metabolites was investigated -glycerol, raffinose, glycerate, ascorbate and others, different amounts at Vitis vinifera and Vitis amurensis (Chai et al., 2019) in the process of frost adaptation. A seasonal dynamic of solid carbohydrate accumulation (starch) and soluble (fructose, glucose, sucrose), the starch is converted in soluble carbohydrate during periods of low temperature (Zuferey et al., 2012).

Application of abscisic acid (ABA) by foliar spraying (Rubio et al., 2019) and some plant beneficial bacteria- Burkholderia phytofirmans Strain Ps (Barka et al., 2006) were proposed for improving resistance to frost of grapevines but there are somehow expensive, hard to apply and results are not constant obtained. A late application of spray with calcium 
chloride looks like to enhance the cold hardiness (Haghi et al., 2019). Pruning of lateral shoots can help because they have less tolerance to cold (Kaya \& Kose, 2017).

The aim of this paper was to evaluate the grapevine buds and wood viability at negative temperatures as well as the content in reserve substances after treatments with copper sulphate.

\section{MATERIALS AND METHODS}

The analysis of the vegetal material was made for frost resistance and viability of winter buds, the degree of wood maturation, free water content (Vila et al., 2010) starch and total carbohydrate content (both for vines treated and to the untreated with Bordeaux mixture (unexposed and exposed for 48 hours at low temperatures) of $-15,-18$ and $-21^{\circ} \mathrm{C}$. The free and bound water content was also analyzed.

\section{RESULTS AND DISCUSSIONS}

The viability of the winter eyes on the treated and untreated vines can be seen from the tables that it is practically $100 \%$, namely those not previously subjected to low temperatures. It is easily observed that the viability even at $-21^{\circ} \mathrm{C}$ is much higher for the vines treated with Bordeaux mixture, which has the property to extract from the existing water in the vines (Table 1) and again this is observed from the other analyzes, as for example, in the analysis of free water weakly related from the collected samples (Table 2) where it is clear that the untreated vines have more free water content, for example sample 1, about $49.642 \%$ compared to $45.282 \%$ for the sample from the treated vines.

Table 1. The influence of temperature on viability of winter buds (\%)

\begin{tabular}{|c|c|c|c|}
\hline Temperature & $-15^{\circ} \mathrm{C}$ & $-18^{\circ} \mathrm{C}$ & $-21^{\circ} \mathrm{C}$ \\
\hline Buds viability (\%)/ Treated vines & 89 & 64 & 55 \\
\hline Buds viability (\%)/ Non treated vines & 58 & 55 & 26 \\
\hline
\end{tabular}

Table 2. The content in water and free water of treated and non-treated vines

\begin{tabular}{|c|c|c|c|}
\hline \multicolumn{2}{|c|}{ Treated vines } & \multicolumn{2}{c|}{ Non treated vines } \\
\hline Sample no & $\begin{array}{c}\text { Free and weak bounded } \\
\text { water (\%) }\end{array}$ & Sample no & $\begin{array}{c}\text { Free and weak } \\
\text { bounded water }(\%)\end{array}$ \\
\hline 1 & 45.281 & 1 & 49.642 \\
\hline 2 & 45.639 & 2 & 47.639 \\
\hline 3 & 44.284 & 3 & 48.431 \\
\hline
\end{tabular}

This correlates with the starch and sugar content of the treated samples having a much higher content than those not treated both as starch and as sugar and as a total carbohydrate expressed as percent (Table 3). We found a better and a simple solution to improve cold hardiness of winter buds and vines.

Table 3. Results of vines samples, content of starch and sugars

\begin{tabular}{|l|l|c|c|c|}
\hline & & Sugars \% & Starch \% & Total carbohydrates \\
\hline 1 & Treated & 7.16 & 3.61 & 10.77 \\
\hline 2 & Treated & 7.27 & 3.42 & 10.69 \\
\hline & Average & $\mathbf{7 . 2 1}$ & $\mathbf{3 . 5 1}$ & $\mathbf{1 0 . 7 3}$ \\
\hline 3 & Not treated & 5.63 & 2.43 & 8.06 \\
\hline 4 & Not treated & 5.69 & 2.45 & 7.86 \\
\hline & Average & $\mathbf{5 . 6 6}$ & $\mathbf{2 . 4 4}$ & $\mathbf{7 . 9 6}$ \\
\hline
\end{tabular}




\section{CONCLUSIONS}

It appears from the presented data that the viability of winter eyes is higher at the same temperature, for those treated with Bordeaux mixture than for those not treated and differs significantly. The biggest difference is found in those exposed to the temperature of $-21^{\circ} \mathrm{C}$, where the treated ones have a viability of $55 \%$ while the untreated ones are only $26 \%$. The presence of weakly bound free water in smaller quantities has a clear role in viability, in the treated ropes it is much lower, so that the vines become much more resistant to frost, due to the known tendency of free water to produce ice crystals, which damage tissues, and normally winter buds.

\section{ACKNOWLEDGEMENTS:}

The researches were funded from the ASAS project no 4690/2018.

\section{REFERENCES}

BARKA, E.A., NOWAK, J., CLEMENT, C. (2006). Enhancement of Chilling Resistance of Inoculated Grapevine Plantlets with a Plant Growth-Promoting Rhizobacterium, Burkholderia phytofirmans Strain Ps JN. Applied Environmental Microbiology, 72, 11, 7246-7252.

CHAI, F., LIU, W., XIANG, Y., MENG, X., SUN, X., CHENG, C., LIU, G., DUAN, L., XIN, H., LIU, S. (2019). Comparative metabolic profiling of Vitis amurensis and Vitis vinifera during cold acclimation. Horticulture Research, 6. DOI 10.1038/s41438-018-0083-5.

EVANS, R.G. (2000). The art of protecting grapevines from low temperature injury. Proceedings of the ASEV 50 th Anniversary Meeting, Seattle, Washington June 19-23, 2000.

FENNELL, A.L. (2004). Freezing Tolerance and Injury in Grapevines. Journal of Crop Improvement, 10, 1-2, 201-23.

FERGUSON, J.C., TARARA, J.M., MILLS, L.J.G., GROVE, G.G., KELLER, M. (2011). Dynamic thermal time model of cold hardiness for dormant grapevine buds. Annals of Botany, 107, 389-396.

HAGHI, H., RABIEI, V., ERSHADI, A., RAZAVI, F. (2019). Effects of Late Season Foliar Application of Calcium Chloride on Cold Hardiness in Grapevines (Vitis vinifera 'Thompson Seedless'). The Horticulture Journal, 88, 3, 347-353.

LONDO, J.P., KOVALESKI, A.P., LILLIS, J.A. (2018). Divergence in the transcriptional landscape between low temperature and freeze shock in cultivated grapevine (Vitis vinifera). Horticulture Research 5, 10. DOI 10.1038/s41438-018-0020-7.

RUBIO, S., NORIEGA, X., PEREZ, F.J. (2019). Abscisic acid (ABA) and low temperatures synergistically increase the expression of $\mathrm{CBF} / \mathrm{DREB} 1$ transcription factors and cold-hardiness in grapevine dormant buds. Annals of Botany, 123, 681-689.

KAYA, Ö., KÖSE, C. (2017). Determination of resistance to low temperatures of winter buds on lateral shoot present in Karaerik (Vitis vinifera L.) grape cultivar. Acta Physiologica Plantarum, 39, 9, 209 (9pp.) DOI 10.1007/s11738-017-2513-7.

VILA, H., HULGALDE, D., FILIPPO, M. (2010). Estimation of leaf water potential by thermographic and spectral measurements in grapevine. Revista de Investigaciones Agropecuarias, 37, 1, 113-126.

WU, J., ZHANG, Y., YIN, L., QU, J., LU, J. (2014). Linkage of cold acclimation and disease resistance through plant- pathogen interaction pathway in Vitis amurensis grapevine. Functional Integrative Genomics, 14, 741-755. DOI 10.1007/s10142-014-0392-1.

ZUFEREY, V., MURISIER, F., VIVIN, P., BELCHER, S., LORENZINI, F., SPRING, J.L., VIRET, O. (2012). Carbohydrate reserve in grapevine (Vitis vinifera L. Chasselas): the influence of the leaves fruit ratio. Vitis, 51, 3, 103-110. 